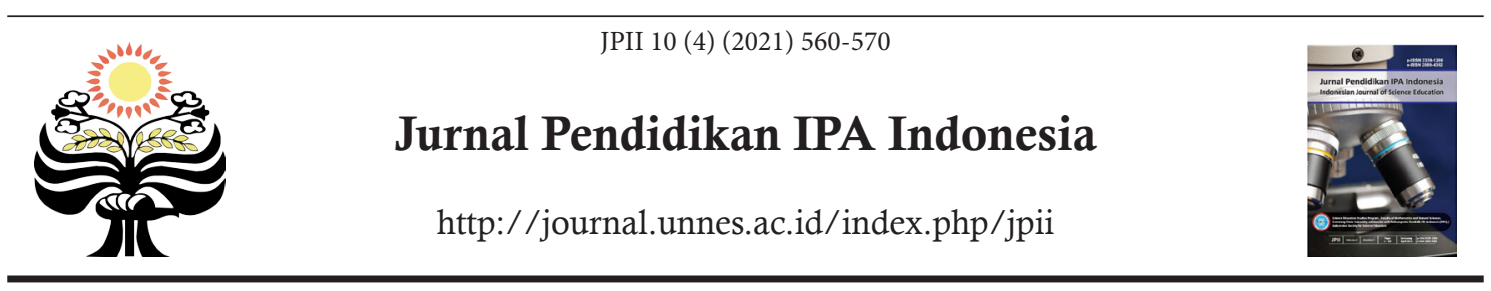

\title{
WATER QUALITY INDEX OF WELL WATER IN THE CONVERTED AGRICULTURAL LAND
}

\author{
R. Prabowo ${ }^{* 1,4}$, A. N. Bambang ${ }^{2}$, Sudarno ${ }^{3}$ \\ ${ }^{1,2,3}$ Postgraduate Environmental Science Program, Universitas Diponegoro, Indonesia \\ ${ }^{4}$ Agribusiness Study Program, Faculty of Agriculture, Universitas Wahid Hasyim, Indonesia
}

DOI: 10.15294/jpii.v10i4.31790

Accepted: August 28 ${ }^{\text {th }}$ 2021. Approved: December 27 $7^{\text {th }} 2021$. Published: December $31^{\text {st }} 2021$

\begin{abstract}
The groundwater condition at converted agricultural land has decreased water quality because of previous agricultural processes, so the water quality index is essential to know. This study aims to measure the groundwater quality index in residential wells on the converted agricultural land, determine the dominant parameters that form the Water Quality Index (WQI) in dug wells and drilled wells on the converted agricultural land, and determine the effect depth and age of wells on WQI. The research design was descriptive exploratory with WQI as the dependent variable and the depth and age of the well as the independent variable. With purposive sampling, 32 points of dug and drilled wells in different locations were chosen. Multiple linear regression was applied for data analysis. From the findings, it can be concluded that the minimum WQI value in dug well water is 76.9, and the average maximum WQI value in dug well water is 92.3 . There are 8 points in dug well water with WQI in a good category or quality-2 category (71-90), and 15 dug well points have WQI in a very good quality category or quality-1 category (91-100). This value indicates that the dug well water quality in the research location is still classified as eligible for consumption. The dominant parameters that form WQI values in dug and drilled wells are manganese, cadmium, iron, with a value of $-0.918-0.886-0.790$. The depth and age of the well affect the water quality index. The depth of the well has a stronger effect on the water quality index than the age of the well.
\end{abstract}

(C) 2021 Science Education Study Program FMIPA UNNES Semarang

Keywords: water quality index; wells; land

\section{INTRODUCTION}

The uncontrolled agricultural land conversion will harm the aspects of farmers' socio-cultural and economy and decrease environmental quality (Prabowo et al., 2020). The conversion of agricultural land into non-agricultural land, especially residential land, harms the people who use groundwater in the converted area. In agriculture, the rapid development of science and technology enables humans to use various chemicals, including heavy metals, to meet agricultural needs such as fertilizers and pesticides. The use of toxic chemicals, such as pesticides and inorganic fertilizers, can trigger changes in quality standards in

*Correspondence Address

E-mail: rossiprabowo@unwahas.ac.id waters, both groundwater and surface water (Wuana \& Okieimen, 2011). Changes in land use and land cover will significantly affect water, especially the quality (Ni et al., 2021). Human activities and natural events can reduce the quality of surface and groundwater (Carpenter et al., 1998; Kazi et al., 2009; Şener et al., 2017). Thus, it is essential to research the converted agricultural land to monitor water quality to maintain the groundwater quality for community needs.

Research on water quality monitoring is needed in areas that can experience water quality degradation. Residential areas converted from rice fields can be contaminated from the remnants of agricultural activities in groundwater used daily. In residential areas, groundwater is often used as a source of clean water in the form 
of well water to meet daily water needs. Groundwater can be either deep well water or dug well water. 7-10 meters below the surface, dug wells are the most prevalent well construction used to collect groundwater for small communities and individual households as drinking water. Dug wells produce water from a layer of soil that is quite close to the surface. Therefore, dug hazardous substances from waste can easily contaminate wells due to community activities. Drilled wells (pumps) are groundwater layers drilled deeper or a layer of soil far from the surface soil can be reached to slightly affected by contamination (Suryana, 2013). Previous research on the quality of well water in the Gunung Putri housing estate, West Java, found four samples that did not meet the quality standards for iron parameters, 1.74 $\mathrm{mg} / \mathrm{L}, 1.998 \mathrm{mg} / \mathrm{L}$, and $1.178 \mathrm{mg} / \mathrm{L}$.

Changes in land use and land cover will significantly affect water quality, which will decrease water quality (Ni et al., 2021). Human activities and natural events can reduce the quality of surface water and groundwater (Carpenter et al., 1998; Kazi et al., 2009; Şener et al., 2017), so it is necessary to monitor water quality to maintain groundwater quality conditions for community needs. Monitoring water quality is essential in areas that can experience water quality degradation. Residential areas converted from rice fields can be contaminated from residual agricultural activities in groundwater used to meet daily water needs. In residential areas, groundwater is often used as a source of clean water to meet daily water needs in the form of well water.

Several methods have been introduced to monitor groundwater quality, including the Water Quality Index (WQI) method (Kannel et al., 2007; Yidana \& Yidana, 2010). WQI is a number that describes water quality by collecting the results of measuring water quality parameters. WQI is an easy and concise method to describe water quality (Lumb et al., 2011). WQI has also been used to observe anthropogenic impacts (Lobato et al., 2015), aquaculture activities (Simoes et al., 2008), and agricultural activities (Koçer \& Sevgili, 2014). Analysis using WQI began in 1965 (Horton, 1965). Over the years, many researchers have developed different methods for calculating WQI (Tsegaye et al., 2006; Saeedi et al., 2009), such as the National Sanitation Foundation Water Quality Index (NSFWQI) from the United States (Brown et al., 1970), Canadian Council of Ministers of the Environment Water Quality Index (CCME WQI) (Khan et al., 2003), British Columbia Water Quality Index (BCWQI), and Oregon Water Quality Index (OWQI) (Kannel et al., 2007).
Water Quality Index (WQI) is considered one of the criteria for classifying surface water based on standard parameters for water characterization. It provides a comprehensive picture of water quality for most household purposes. WQI is a mathematical instrument used to convert large amounts of water characterization data into a single number, representing the water quality level (Bordalo et al., 2006; Sánchez et al., 2007). Water quality assessment with WQI can simplify information about the water condition, which makes it easier to determine suitable water conditions for supporting life activities (Pesce \& Wunderlin, 2000; Lobato et al., 2015).

The NSF WQI is a standard method for comparing water quality based on nine parameters: temperature, dissolved oxygen, $\mathrm{pH}$, turbidity, biochemical oxygen demand, total phosphate, nitrate, fecal coliform, and total solids. The classification of water quality from the results of the WQI calculation is categorized into very good, good, regular, poor, and very poor (Chaturvedi \& Bassin, 2010). Various studies were carried out for the assessment of water quality of various water bodies using WQI (Akbal et al., 2011; Abdulwahid, 2013; Hefni \& Romanto, 2015; Lobato et al., 2015). Parameters that do not meet the standard requirements for drinking water quality on rice field conversion include iron, lead, color, smell, and taste, so they are not suitable for drinking but can still be used as clean water (Yuliani et al., 2017).

The potential for water contamination in wells on residential land converted from agricultural land and the research findings that mention the presence of iron, lead, color, odor, and taste contamination requires an effort to monitor water quality using WQI. By monitoring using WQI, it is expected to know the WQI and the dominant parameters that affect well water quality in converted agricultural land. The conditions of different wells, in their depth and age, need to be studied to obtain information regarding the effect on the water quality index. The novelty in this study is monitoring water quality in converted agricultural land using the WQI method while knowing the dominant parameters with variations in depth and age of the well.

This study aims to measure the groundwater quality index in residential wells on the converted agricultural land, determine the dominant parameters that form the Water Quality Index (WQI) in dug wells and drilled wells on the converted agricultural land, and determine the effect depth and age of wells on WQI. The water quality was measured using the Water Quality Index (WQI) method. Converted agricultural land in 
this study is agricultural land converted into residential land in Semarang. Research findings are needed as information on water quality categories in converted agricultural land, the dominant parameters that form WQI in residential wells, and the effect of depth and age of wells on the water quality index.

\section{METHODS}

This research was conducted in Tembalang District, Semarang, in the location of land conversion into housing. The location was selected based on a map of land conversion in Semarang from 2000 to 2019. The research was carried out in 2020. The research design was descriptive exploratory (Nazir, 2005), research on a condition by making a systematic, factual, and accurate description of facts and characteristics and examining the relationship between observed phenomena. In this study, the variables observed were the water quality index (WQI) of the converted agricultural land, environmental parameters, well depth in meters, and age of wells in years. Groundwater samples in dug and drilled wells at 32 different locations were determined by purposive sampling. The administrative map of Semarang is presented in Figure 1.

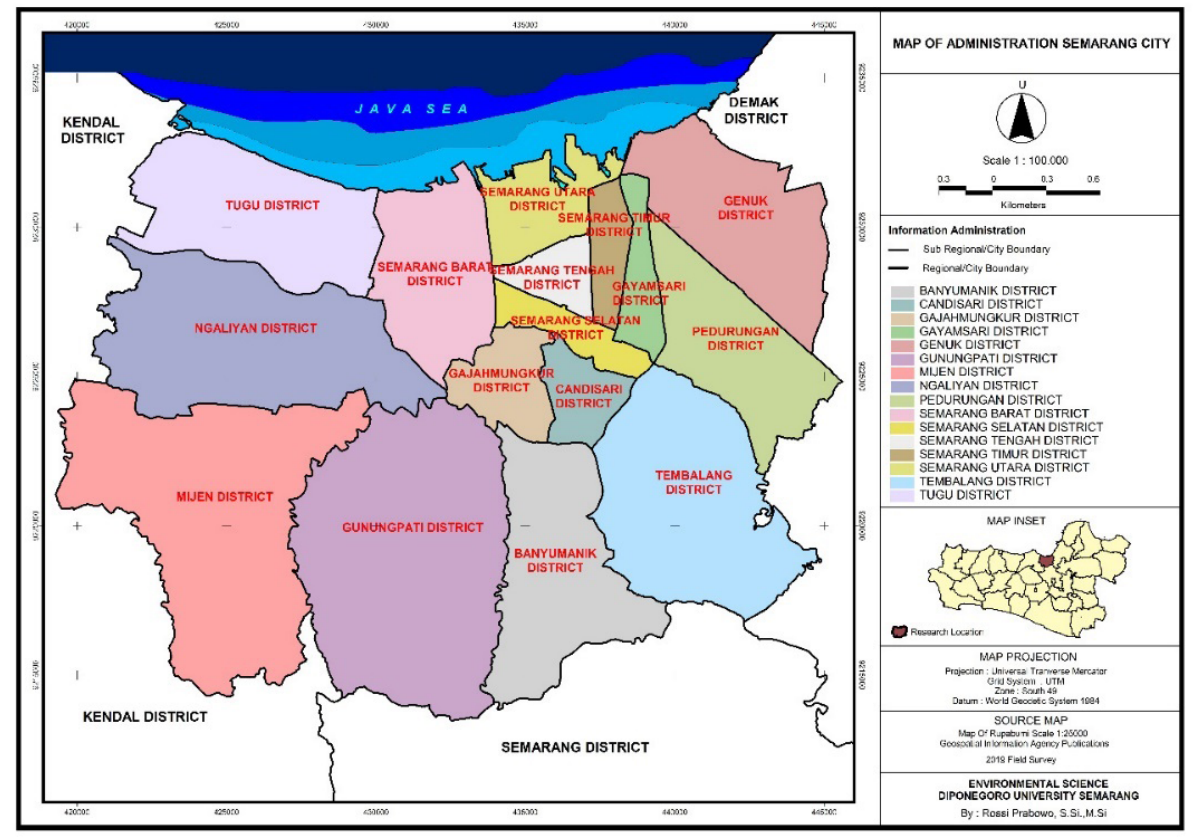

Figure 1. Administrative Map of Semarang City (processed with ArcGIS)

Topographically, Semarang City consists of hills, lowlands, and coastal areas. The city of Semarang shows various slopes and protrusions. It is heavily impacted by its natural surroundings, including mountainous, lowland, and coastal environments. Semarang's geography reveals diverse land slopes ranging from $0 \%$ to $40 \%$ (steep) and altitudes ranging from 0.75 to 348.00 masl.

The hydrological conditions of water potential in Semarang City originate from rivers, including Garang River, Pengkol River, Kreo River, East Banjir Kanal River, Babon River, Sringin River, Kripik River, Dungadem River, and many more. These rivers affect the condition of groundwater in Semarang. Free groundwater is found in the water-carrying layer (aquifer) and is not covered by an impermeable layer. Its surface is strongly influenced by the seasons and the state of the surrounding environment. Semarang residents in the lowlands mostly take advantage of this groundwater by making dug wells (shallow) with an average depth of $3-18 \mathrm{~m}$, while residents in the highlands can only use dug wells in the rainy season with depths ranging from $20-40$ meters.

WQI calculates the groundwater quality index in residential wells. The WQI calculation stage converts measurement results from 13 water quality parameters with various units into values on a scale of 0 to 100 without units (Pesce \& Wunderlin, 2000; Kannel et al., 2007). Thirteen parameters to measure water quality in this study were turbidity, nitrate, temperature, TDS, iron, cadmium, hardness, chloride, manganese, nitrate, $\mathrm{pH}$, sulfate, and lead. In this study, the thirteen parameters were given a score of 1 if they were under the requirements of clean water quality and 0 if they were not. The WQI value is calculated based on each parameter scored, divided by 13, and multiplied by 100 . 
Based on the resulting WQI value, water conditions can be classified into five classes (Pesce \& Wunderlin, 2000; Kannel et al., 2007) (Table 1).

Table 1. Water Quality Classification Based on WQI Value

\begin{tabular}{ccc}
\hline Class & WQI Value & Classification \\
\hline 1 & $91-100$ & Very Good \\
2 & $71-90$ & Good \\
3 & $51-70$ & Regular \\
4 & $26-50$ & Poor \\
5 & $0-25$ & Very Poor \\
\hline
\end{tabular}

Parameter measurement data and calculation results of WQI were tested by t-test to determine the difference between the water conditions of the drilled and dug well. In addition, a descriptive analysis of the water quality parameter data and the value of WQI was also carried out in tables and graphs. The dominant parameters that form WQI can be determined by correlation analysis. Correlation analysis was carried out to see the relationship of each parameter to the WQI value. The effect of the depth and age of the well on the water quality index is analyzed using multiple linear regression (Kocer \& Sevgili, 2014). This analysis aims to determine the main factors affecting the WQI value in two types of wells (dug and drilled wells). Before performing multiple regression analysis, a multicollinearity test was conducted to determine a perfect relationship between the independent variables. Multicollinearity detection used the tolerance value and VIF (variance inflation factor), where if the
Tolerance value is less than 0.1 and the VIF is more than 10 , then multicollinearity occurs. If there is multicollinearity, then a stepwise regression analysis is carried out, where all parameters are entered into the equation or removed from the equation in stages to determine their relative importance to WQI as the dependent variable (Supranto, 2010). The independent variables in this study were the depth and the age of the well, and the dependent variable was the water quality index (WQI).

\section{RESULTS AND DISCUSSION}

Water, a basic need for living things on earth, is declining in quality. The decline in water quality is caused by contamination of various kinds of waste, domestic and industrial waste, entering water bodies. Industrial and agricultural activities that aim to improve the quality of human life also harm the environment and human life (Wardhana, 2004). All human activities, such as industrial, residential, and agricultural activities, will create waste that leads to the degradation of water quality (Suriawiria, 2005).

Parameter measurement data and calculation results of WQI were tested by t-test (Santoso, 2014) to determine differences in water conditions between dug and drilled wells. In addition, descriptive analysis was also carried out on water quality parameter data and the resulting WQI value, which is shown in tables and graphs. Twenty-three dug wells consist of 22 dug wells in the rice field conversion land (DGW 1-22) and one well dug in the non-rice-field conversion land as a control (DGW 31). WQI value for each observation point in the dug well is in Figure 2.

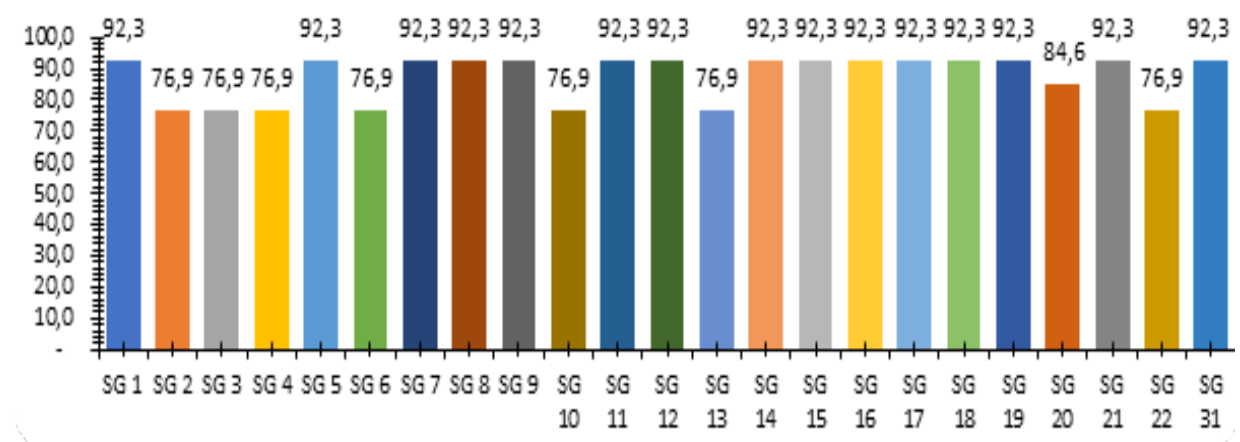

Figure 2. WQI Value for Each Observation Point in the Dug Well

Figure 2 shows the groundwater quality index based on the WQI value in residential wells, converted agricultural land in general. The minimum WQI value in dug well waters is 76.9 , and the maximum is 92.3 . Of the $23 \mathrm{dug}$ well points,
15 dug well points have a very good WQI quality category or are in the quality-1 category (91-100), and the eight dug well points have a good category or are in the quality-2 category (71-90). This value indicates that the water quality in the dug 
wells at the study site still meets the requirements for consumption. This result is under the opinion of Yuliani et al. (2017), who explained that the pollution index in converted agricultural land in the Gunung Putri housing estate, West Java, shows the water pollution level from drilled wells still meets the quality standards for clean water quality.

The findings in this study are that even though the WQI assessment is in a good category, there are 7 dug well points with cadmium levels exceeding the threshold $(>0.005 \mathrm{mg} / \mathrm{l})$ in the range of $0.0051-0.007 \mathrm{mg} / 1$. There are eight dug wells where the manganese content exceeds the limit $(>0.5)$, with a range of 0.507 to 0.785 . The content of cadmium and manganese that exceeds the threshold of quality standards is one indicator of contamination or contamination of dug well water so that it is not good for use as a source of consumption raw materials. This result is under the statement of Pesce \& Wunderlin (2000), which states that the water classified as very good does not show any contamination (high clarity or low suspended matter content). The heavy metal contamination of cadmium and manganese in well water is due to the infiltration process from previous agricultural activities, such as excessive use of fertilizers and pesticides, which then settles and becomes trapped in the soil and over time enters the groundwater. (Widianingrum, 2007; Prabowo, 2017).

WQI value for each observation point in the drilled well is presented in Figure 3.

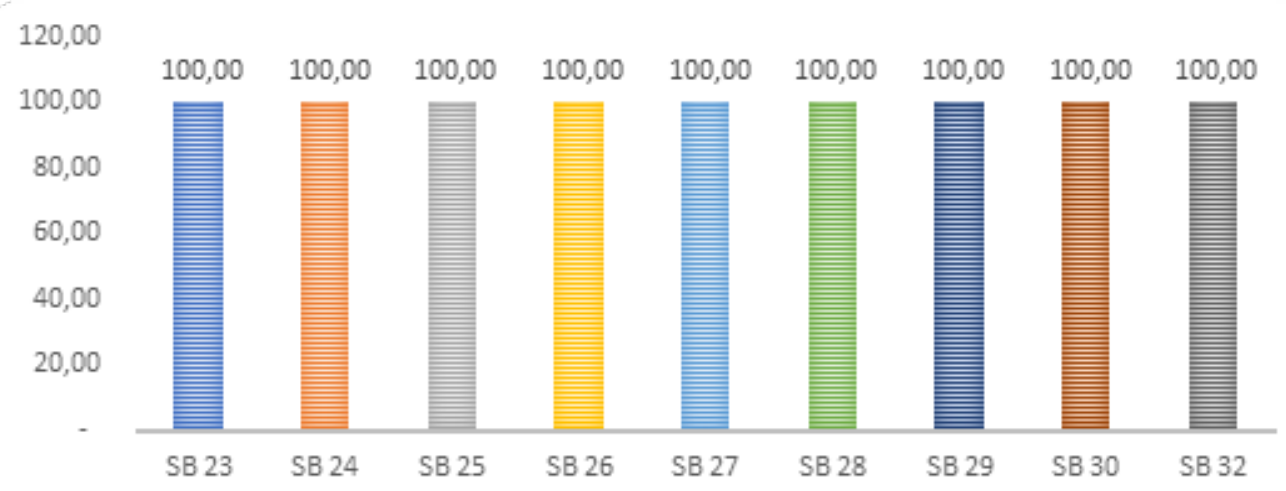

Figure 3. WQI Value for Each Observation Point in the Drilled Well

The nine drilled wells observed consist of eight drilled wells in the rice field conversion land (DRW 23-30) and one drilled well in the non-rice-field conversion land as a control (DRW 32). The water conditions of 8 drilled wells in housing from agricultural conversion land have a $100 \%$ WQI average. This condition is the same as the drilled well waters in control well (DRW 32). The WQI value for drinking water quality from drilled wells on rice field conversion land is still in category one or very good quality (91-100), so it can be used as raw material for drinking water and to fulfill the needs of human life. The condition of the drilled well waters consists of 8 points and has an average WQI of 100 percent, so that based on the WQI value, the quality of drinking water in drilled well waters on converted agricultural land is still categorized as quality-1 or very good (91-100) so it can still be used as raw material for drinking water and can be used to meet the needs of human life. Parameters of turbidity, nitrite, temperature, TDS, iron, cadmium, hardness, chloride, manganese, nitrate, $\mathrm{pH}$, sulfate and lead are still under the established quality standards. According to Arsyad (2000), water quality is determined from the level of suitability of water to be used to fulfill the needs of human life, such as to irrigate crops, drink livestock, and immediate needs for drinking, bathing, washing, and many more. Water quality is determined by suspended sediment and chemicals dissolved in the water. The higher the chemical content, the lower the well water quality. The quality of drilled well water has met the requirements for clean water quality to meet household needs as stated in the Regulation of the Minister of Health of the Republic of Indonesia No. 82/2001 concerning requirements for clean water quality to fulfill household needs and a list of clean water quality requirements according to the Minister of Health of the Republic of Indonesia No. 416/MENKES/PER/1990.

The t-test was conducted to determine the dominant parameters that formed WQI in dug and drilled wells at converted agricultural land. The results of the t-test comparing the water quality index based on each parameter in dug wells and drilled wells can be seen in Table 2 . 
Table 2. T-test Results in Comparison of Water Quality Index Based on Each Parameter Between Dug Wells and Drilled Wells

\begin{tabular}{lccccccccc}
\hline \multirow{2}{*}{ Variable } & \multicolumn{3}{c}{ Dug Wells $(\mathbf{n}=\mathbf{2 3})$} & \multicolumn{7}{c}{ Drilled Wells $(\mathbf{n}=\mathbf{9})$} \\
\cline { 2 - 9 } & Average & stdev & Min & Max & Average & Stdev & Min & Max & p-value \\
\hline Turbidity & 4.237 & 2.794 & 1.480 & 12.630 & 0.327 & 0.085 & 0.210 & 0.460 & 0.000 \\
Nitrite & 0.031 & 0.010 & 0.008 & 0.057 & 0.001 & 0.000 & 0.001 & 0.001 & 0.000 \\
Temperature & 23.796 & 0.351 & 23.200 & 24.800 & 23.667 & 0.173 & 23.400 & 23.900 & 0.304 \\
TDS & 656.391 & 70.653 & 458.000 & 769.000 & 784.889 & 129.249 & 619.000 & 937.000 & 0.018 \\
Iron & 0.152 & 0.135 & 0.019 & 0.472 & 0.019 & 0.000 & 0.019 & 0.019 & 0.000 \\
Cadmium & 0.003 & 0.002 & 0.001 & 0.007 & 0.001 & 0.000 & 0.001 & 0.001 & 0.002 \\
Hardness & 282.217 & 38.090 & 239.600 & 391.500 & 237.122 & 15.344 & 219.300 & 260.900 & 0.002 \\
Chloride & 71.514 & 8.493 & 58.290 & 90.170 & 78.922 & 9.437 & 67.660 & 90.180 & 0.040 \\
Manganese & 0.295 & 0.255 & 0.032 & 0.785 & 0.032 & 0.000 & 0.032 & 0.032 & 0.000 \\
Nitrate & 0.261 & 0.067 & 0.040 & 0.370 & 0.277 & 0.084 & 0.090 & 0.380 & 0.591 \\
pH & 7.652 & 0.262 & 7.180 & 8.110 & 7.846 & 0.275 & 7.380 & 8.150 & 0.073 \\
Sulfate & 134.478 & 23.407 & 98.000 & 183.000 & 182.222 & 15.320 & 158.000 & 210.000 & 0.000 \\
Lead & 0.009 & 0.000 & 0.009 & 0.009 & 0.009 & 0.000 & 0.009 & 0.009 & 0.000 \\
\hline Source: Processed Data, 2020 & & & & & & & &
\end{tabular}

The T-test results showed the difference between the average WQI value in dug and drilled wells waters $(p<0.05)$. The difference in WQI values in dug wells and drilled wells are influenced by the parameters of turbidity, nitrite, TDS, iron, cadmium, hardness, chloride, manganese, sulfate, and lead, while the low average WQI value between dug wells and drilled wells ( $p$ $>00.05$ ) exists in the parameters of temperature, nitrate, $\mathrm{pH}$. This result shows that the parameters of turbidity, nitrite, TDS, iron, cadmium, hardness, chloride, manganese, sulfate, and lead have significant differences in dug and drilled wells. Differences in turbidity parameters, nitrite, TDS, iron, cadmium, chloride, manganese, and sulfate in dug and drilled wells are because of well type. Dug wells have higher levels of turbidity, nitrite, iron, cadmium, and manganese than drilled wells because dug wells have a shorter depth than drilled wells, resulting in surface water infiltration of materials and compounds stored in the soil from previous agricultural activities was easier to enter the dug well water. This statement follows Prabowo's (2017) opinion, which states that agricultural activities negatively impact groundwater quality because of the contamination of nitrite and heavy metals such as cadmium and manganese. Furthermore, multiple correlation analysis was carried out to see the relationship of each parameter to the WQI value (Dahlan, 2012). Maskooni et al. (2020) stated that WQI was measured by looking at the water content. Multiple correlation analysis aims to determine the main parameters that influence the formation of WQI values at the two research sites (drilled wells and dug wells).

Correlation Test Results between Parameter and WQI can be seen in Table 3. Analysis of the relationship of each parameter with the average WQI is mostly negatively correlated. It means that the higher the level of parameters in the waters, both drilled wells and dug wells, the lower the water quality. On the other hand, the lower the level of parameters in the waters, both drilled and dug wells, the higher the water quality. Table 3 shows that the most significant parameters influencing the WQI value are manganese, cadmium, and iron with $-0.918-0.886-0.790$, respectively. Manganese, cadmium, and iron are compounds contained in fertilizers and pesticides, so it can be said that the excessive use of agricultural fertilizers in agricultural activities has resulted in contamination of groundwater in well water in housing from agricultural land conversions. The magnitude of the effect of this compound indicates that agricultural activities have a considerable influence on groundwater quality. This statement follows Widaningrum et al. (2007), which states that excessive use of fertilizers is not beneficial for land and environmental sustainability because of the high fertilizer residue in the land. Continuous fertilization causes high fertilizer residues in the soil and increases the content of heavy metals $\mathrm{Pb}$ (lead) and Cd (cadmium). 
Table 3. Correlation Test Results between Parameter and WQI

\begin{tabular}{clccl}
\hline No & \multicolumn{1}{c}{ Parameter } & R count & p-value & \multicolumn{1}{c}{ Conclusion } \\
\hline 1 & Turbidity & $-0,660$ & 0,000 & Significant \\
2 & Nitrite & $-0,606$ & 0,000 & Significant \\
3 & Temperature & $-0,023$ & 0,901 & Not significant \\
4 & TDS & 0,491 & 0,004 & Significant \\
5 & Iron & $-0,790$ & 0,000 & Significant \\
6 & Cadmium & $-0,886$ & 0,000 & Significant \\
7 & Hardness & $-0,663$ & 0,000 & Significant \\
8 & Chloride & 0,062 & 0,738 & Not significant \\
9 & Manganese & $-0,918$ & 0,000 & Significant \\
10 & Nitrate & 0,027 & 0,885 & Not significant \\
11 & pH & 0,224 & 0,218 & Not significant \\
12 & Sulfate & 0,602 & 0,000 & Significant \\
13 & Lead & - & - & It cannot be concluded \\
\hline
\end{tabular}

The following analysis is a multiple linear regression analysis to determine the effect of the depth and age of the well on the WQI value (Koçer \& Sevgili, 2014). Multiple linear regression analysis aims to determine the influence of the dominant factor between depth and age of the well on water quality (WQI) at the two research sites (drilled well and dug well). Before performing multiple regression analysis, the analysis requirements test was first carried out: the classical assumption test, consisting of normality, heteroscedasticity, and autocorrelation tests. The classical assumption test was carried out on the regression equation to see the effect of the depth and age of the well on the WQI. A good regression model must meet the requirements of the classical assumptions: A normal distribution must be met, there must be no correlation between independent variables or multicollinearity, and there must be no autocorrelation. The normality test whether the confounding variable or residual has a normal distribution in the regression model. Normality test research using graph analysis. Graph analysis is done by processing the data into a histogram and normal probability plots. The normality test result can be seen in Figure 4.

Histogram

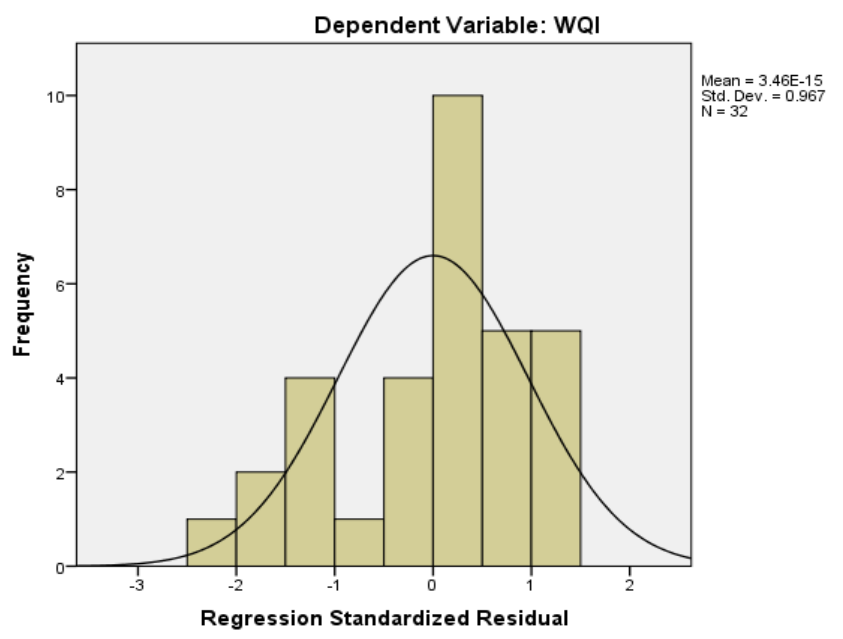

Figure 4. Normality Test Results with Graphs

Based on the scatter plot image, it can be seen that the histogram of each is in a balanced curve between left and right, not skewed to the left or right, indicating that the data in this study is normally distributed. The purpose of multicollinearity is to see if the independent variables in a regression model have a substantial correlation. The tolerance value and variance inflation factor
(VIF) are used to perform multicollinearity testing. It may be concluded that there is no multicollinearity between independent variables in the regression model if the tolerance value is more than 0.10 or the VIF is less than 10 (Ghozali, 2013). The following are the results of the multicollinearity test of the model after the outliers as shown in Table 4. 
Table 4. Multicollinearity Test Results

\begin{tabular}{lcc}
\hline \multirow{2}{*}{ Model } & \multicolumn{2}{c}{ Collinearity Statistics } \\
\cline { 2 - 3 } & Tolerance & VIF \\
\hline $\begin{array}{l}\text { 1. Dependent Variable: WQI } \\
\text { Depth }\end{array}$ & 0,994 & 1,006 \\
Age & 0,994 & 1,006 \\
\hline Source: Processed Secondary Data, 2020 &
\end{tabular}

Source: Processed Secondary Data, 2020

Table 4 shows that each tolerance value is 0.994 , and each tolerance value is 1.006 in the regression equation. The tolerance value of all variables is more significant than 0.1 , and the VIF value of all variables is below the number 10 . So, the independent variables used in the regression model do not show any symptoms of multicollinearity.

Table 5. Autocorrelation Test Results
The autocorrelation test (Santoso, 2014) aims to find out whether there is a correlation between the confounding error in period $t$ (current) and errors in period $t-1$ (previous) in a regression model. This autocorrelation test used the DurbinWatson test (DW test). Autocorrelation test result can be seen in Table 5 .

\begin{tabular}{cc}
\hline \multicolumn{1}{c}{ Model } & Durbin-Watson Value \\
\hline 1. Dependent Variable: WQI & 2,086 \\
\hline Source: Processed Secondary Data, 2020 &
\end{tabular}

The results of the autocorrelation test with the Durbin-Watson test on the regression equation obtained a value of 2.086 . The DW value of the regression equation is between 1.65 and 2.35 , so there is no autocorrelation in the model $(\mathrm{Su}-$ laiman, 2004). It can be concluded that the regression model in this study has no symptoms of autocorrelation. The multiple linear regression analysis results consist of coefficient of determination test, simultaneous test ( $F$ test), and partial test (t-test). The coefficient of determination aims to determine and measure how far the model can explain variations in the dependent variable. The value of the coefficient of determination is between zero and one (Ghozali, 2013). The coefficient of the determination test result is in Table 6.

Table 6. Coefficient of Determination Test Results

\begin{tabular}{|c|c|c|c|c|c|c|c|c|}
\hline Model & $\mathbf{R}$ & R Square & \multicolumn{3}{|c|}{ Adjusted R Square } & \multicolumn{3}{|c|}{ Std. Error of the Estimate } \\
\hline 1 & 0,742 & 0,550 & \multicolumn{3}{|c|}{0,519} & \multicolumn{3}{|c|}{5,817} \\
\hline \multicolumn{9}{|c|}{ Source: Processed Secondary Data, 2020} \\
\hline \multicolumn{4}{|c|}{$\begin{array}{l}\text { In Table } 6 \text {, the coefficient of determination } \\
\text { is } 0.550 \text { or } 55.0 \% \text {. The coefficient of } 55 \% \text { means } \\
\text { that the water quality index can be explained by } \\
\text { the variable depth and the age of the well. The } \\
\text { remaining } 45 \% \text { is explained by other factors not } \\
\text { examined in this study. The result of the second } \\
\text { multiple linear regression test is the F test. It aims } \\
\text { to determine that all the independent variables re- }\end{array}$} & \multicolumn{5}{|c|}{$\begin{array}{l}\text { ferred to in the model can predict the water qua- } \\
\text { lity index variable. The F test is carried out by } \\
\text { looking at the significance value of F on the SPSS } \\
\text { output with a significance level of } 0.05(\alpha=5 \%) \text {. } \\
\text { If the significance value is less than } \alpha \text {, the hypot- } \\
\text { hesis is accepted, the regression model is feasible } \\
\text { or fit. The F test result is in Table } 7 \text {. }\end{array}$} \\
\hline \multicolumn{9}{|c|}{ Table 7. F Test Results } \\
\hline \multicolumn{2}{|r|}{ Model } & \multicolumn{2}{|c|}{ Sum of Squares } & Df & \multicolumn{2}{|c|}{ Mean Square } & $\mathbf{F}$ & Sig. \\
\hline \multirow{3}{*}{. } & Regression & 1200,563 & & 2 & \multirow{2}{*}{\multicolumn{2}{|c|}{$\begin{array}{c}600,281 \\
33,841\end{array}$}} & 17,738 & $0,000^{\mathrm{b}}$ \\
\hline & Residual & 981,390 & & 29 & & & & \\
\hline & Total & 2181,953 & & 31 & & & & \\
\hline
\end{tabular}


In Table 7, the $\mathrm{F}$ test obtained a significance value of the first equation of 0.000 , smaller than the level of $=0.05$. These results indicate that the regression model in the study is feasible or fit.
The result of the subsequent regression analysis is the t-test. Linear regression analysis produces regression coefficients to construct the regression equation. It is presented along with the T-test result in Table 8.

Tabel 8. T-test Results

\begin{tabular}{lccccc}
\hline \multicolumn{1}{c}{ Model 1 } & \multicolumn{1}{c}{ Unstandardized Coefficients } & Standardized Coefficients & T & Sig. \\
\hline & $\boldsymbol{B}$ & Std. Error & Beta & & \\
\hline (Constant) & 82,923 & 2,147 & & 38,626 & 0,000 \\
Depth (meter) & 0,138 & 0,026 & 0,676 & 5,413 & 0,000 \\
Age & 0,693 & 0,335 & 0,258 & 2,065 & 0,048 \\
\hline
\end{tabular}

Source: Processed Secondary Data, 2020

The test results obtained a constant of 82,923 . It means that if the other independent variables remain constant, then the WQI of 82,923 is in the good quality category. The well depth regression coefficient is 0.138 . It means that if the other independent variables remain constant with an increase in depth of the well of 1 unit, the WQI will increase by 0.138 points. The regression coefficient for the age of the well is 0.693 . It means that if the other independent variables remain constant and the age of the well increases by 1 unit, the WQI will increase by 0.693 points.

The t-statistical test aims to see the effect of each independent variable individually on the dependent variable. Table 6 shows that the well depth variable has a significance value of 0.000 less than 0.05 , t count is 5.413 , and the regression coefficient is positive at 0.138 , so it can be concluded that well depth has a significant positive effect on WQI. These results mean that the higher the depth of the well, the better the water quality. So the first hypothesis, which states that the depth of the well has a positive effect on WQI, is accepted.

Table 6 shows that the well-age variable has a significance value of 0.048 less than 0.05 , $t$ count of 2.065 , and the regression coefficient is positive at 0.693 , so the age of the well has a strong positive influence on WQI, it can be determined. It means that the older the well, the better the water quality. So the second hypothesis, which states that the age of the well has a positive effect on WQI, is accepted.

The study results stated that the depth of the well had a significant positive effect on WQI. The classification of water quality in this study is based on the WQI value developed by Kannel et al. (2007) and Pesce \& Wunderlin (2000) (in Haryadi et al., 2016). The lower the water material content, the better the water quality. On the contrary, the higher the water material content, the lower the water quality (Bartram, 1996). The results of this study determine the evidence that depth to the surface affects water quality. The deeper the surface of the well, the better the water quality (Ekere et al., 2019), and the shallower the surface of the well, the worse the water quality (Olasoji et al., 2019).

This study can explain that the depth of the groundwater table is the highest surface of the water that rises to the top of a well. The degradation and contamination of groundwater are affected by the depth and type of the well (Maran et al., 2016). The groundwater level is influenced by soil type, rainfall, evaporation, and open flow conditions (rivers). The groundwater table depth will affect the vertical distribution of compounds, active ingredients, heavy metals, and coliform bacteria. Soil contamination by a compound, active ingredient, heavy metal, and bacteria can reach a depth of 3 meters from the soil surface. Drilled wells have a deeper depth than dug wells, so they have better water quality.

The effect of the depth and age of the well on the water quality index states that the age of the well has a significant positive effect on WQI. The older the well, the better the water quality. The younger the age of the well, the worse the water quality. It shows that the better water quality in old wells is due to the decreasing number of compounds, active ingredients, and heavy metals that settle in the soil layer of former rice fields from the rest of previous agricultural activities. Young wells still get contaminated with active compounds and heavy metals that settle on the soil layer from previous agricultural activities. This statement follows the opinion of Maria et al. (2014), which explains that the age of the well is related to the length of time the well is 
used. Wells that have been used for a long time and the volume of water taken is relatively large cause groundwater flow around the well to be higher and dominant. The sources of pollution around the well are increasing in line with the development of human activities. It gives a greater opportunity for the seepage of compounds, active ingredients, heavy metals, and bacteria from the pollutant source into the well. The pollutant source seeps into the well following the flow of groundwater that is concentrated towards the well. The same thing is also explained by Syamsir et al. (2019) that the development of WQI based on well water quality measurements can provide accurate results of well water quality information utilized by the community.

\section{CONCLUSION}

Groundwater conditions in dug wells and drilled wells in housing in Semarang have an average minimum WQI value in dug well waters of 76.9 and an average maximum WQI value of 92.3. The dominant parameters that form WQI values in dug and drilled wells are manganese, cadmium, and iron with $-0.918-0.886-0.790$, respectively. Even though the WQI assessment is in a good category, there are 7 dug well points with cadmium levels exceeding the threshold $(>0.005$ $\mathrm{mg} / \mathrm{l}$ ) in the range of $0.0051-0.007 \mathrm{mg} / 1$. There are eight dug wells where the manganese content exceeds the limit $(>0.5)$, with a range of 0.507 to 0.785 . The depth and age of the well have a positive effect on the water quality index, and the depth of the well has a more substantial effect on the water quality index than the age of the well.

\section{REFERENCES}

Abdulwahid, S. J. (2013). Water quality index of delizhiyan springs and Shawrawa river within Soran district, Erbil, Kurdistan region of Iraq. $J$ Appl Environ Sci, 3, 40-48.

Akbal, F., Gürel, L., Bahadır, T., Güler, İ., Bakan, G., \& Büyükgüngör, H. (2011). Multivariate statistical techniques for the assessment of surface water quality at the mid-black sea coast of Turkey. Water, Air, \& Soil Pollution, 216(1), 21-37.

Arsyad, S. (2000). Konservasi Tanah dan Air. Serial Pustaka IPB. Press.Bogor.

Bartram, J. (1996). Water Quality Monitoring. A practical guide to the design and implementation of freshwater quality studies and monitoring programs (R. Ballance (ed.); 1st ed.). E\&FN Spon.

Bordalo, A. A., Teixeira, R., \& Wiebe, W. J. (2006) A Water Quality Index Applied to an International Shared River Basin: The Case of the Douro
River. Environmental Management, 38, 910-920.

Carpenter, S. R., Caraco, N. F., Correll, D. L., Howarth, R. W., Sharpley, A. N., \& Smith, V.H., (1998). Nonpoint pollution of surface waters with phosphorus and nitrogen. Ecol. Appl. 8, 559-568.

Chaturvedi, M. K., \& Bassin, J. K. (2010). Assessing the water quality index of water treatment plant and bore wells, in Delhi, India. Environ Monit Assess, 163, 449-453.

Dahlan, M. S. (2012). Statistik Untuk Kedokteran dan Kesehatan: Deskriptif, Bivariat, Multivariat, Dilengkapi Dengan Menggunakan SPSS Edisi 5. Jakarta: Salemba Medika.

Ekere, N. R., Agbazue, V. E., Ngang, B. U., \& Ihedioha, J. N. (2019). Hydrochemistry and Water Quality Index of groundwater resources in Enugu north district, Enugu, Nigeria. Environmental Monitoring and Assessment, 191(3), 10661.

Ghozali, I. (2013). Aplikasi Analisis Multivariate dengan Program IBM SPSS 21. Semarang: Universitas Diponegoro.

Haryadi, J., Erlania. \& Radiarta, I. N., (2015). Analisis Indeks Kualitas Perairan Berdasarkan Parameter Nutrien Di Perairan Ujung Genteng, Jawa Barat Dan Labuhanbua, Nusa Tenggara Barat.

Hefni, E., \& Romanto, Y. W. (2015). Water quality status of Ciambulawung River, Banten Province, based on pollution index and NSF-WQI. Procedia Environ Sci, 24, 228-237.

Horton, R. K., (1965). An index number system for rating water quality. J. Water Pollut. Control Fed. 37(3), 300-306.

Kannel, P. R., Lee, S., Lee, Y. S., Kanel, S. R. \& Khan, S.P. (2007). Application of Water Quality Indices and dissolved oxygen as indicators for river water classification and urban impact assessment. Environ. Monit. Assess., 132, 93-110.

Kazi, T., Arain, M. B., Jamali, M. K., Jalbani, N., Afridi, H. I., Sarfraz, R. A., Baig, J. A., \& Shah, A. Q. (2009). Assessment of water quality of polluted lake using multivariate statistical techniques: a case study. Ecotoxicol. Environ. Saf. 72, 301-309.

Koçer, M. A., \& Sevgili, H. (2014). Parameters selection for water quality index in the assessment of the environmental impacts of land-based trout farms. Ecological Indicators, 36, 672-681.

Lobato, T. C., Hauser-Davis, R. A., Oliveira, T. F., Silveira, A. M., Silva, H. A. N., Tavares, M. R. M. \& Saraiva, A. C. F. (2015). Construction of a novel water quality index and quality indicator for reservoir water quality evaluation: A case study in the Amazon region. Journal of Hydrology, 522, 674-683.

Lumb, A., Sharma, T. C., \& Bibeault, J. F. (2011). A review of genesis and evolution of water quality index (WQI) and some future directions. Water Quality, Exposure and Health, 3(1), 11-24.

Maskooni, E. K., Naseri-Rad, M., Berndtsson, R., \& Nakagawa, K. (2020). Use of heavy metal con- 
tent and modified water quality index to assess groundwater quality in a semiarid area. Water (Switzerland), 12(4).

Maran, N. H., Crispim, B. D. A., Iahnn, S. R., de Araújo, R. P., Grisolia, A. B., \& de Oliveira, K. M. P. (2016). Depth and well type related to groundwater microbiological contamination. Depth and Well Type Related to Groundwater Microbiological Contamination International Journal of Environmental Research and Public Health, 13(10).

Maria, R., Mulyadi, D., Lestiana, H. \& Sugianti, K., (2014). Pengaruh Kondisi Lingkungan Terhadap Kualitas Airtanah Bebas Di Pangalengan Kabupaten Bandung. Prosiding Pemaparan Hasil Penelitian Pusat Penelitian Geoteknologi Lipi.

Nazir, M. (2005). Metode Penelitian. Jakarta: Ghalia Indonesia.

Ni, X., Parajuli, P. B., Ouyang, Y., Dash, P., \& Siegert, C. (2021). Assessing land use change impact on stream discharge and stream water quality in an agricultural watershed. Catena, 198, 105055.

Olasoji, S. O., Oyewole, N. O., Abiola, B., \& Edokpayi, J. N. (2019). Water quality assessment of surface and groundwater sources using a water quality index method: A case study of a peri-urban town in southwest, Nigeria. Environments, 6(2), 23.

Pesce, S. F., \& Wunderlin, D. A. (2000). Use of water quality indices to verify the impact of Cordoba city (Argentina) on Suquýa River. Water Res., 34, 2915-2926.

Prabowo, R., Bambang. A. N., Sudarno., \& Nurlette, A. R (2020). Identification and conversion rate of rice field in Semarang year 2000-2019. E3S Web of Conferences, 202, 02002 (2020) ICENIS 2020.

Prabowo, R. (2017) Kadar Nitrit Pada Sumber Air Sumur Di Kelurahan Meteseh, Kec. Tembalang, Kota Semarang. J. Cendekia Eksakta, 1(2).

Saeedi, M., Abessi, O., Sharifi, F Maraji, H., (2009). Development of groundwater quality index. Environ. Monit. Assess. 163 (1-4), 327-335.

Sánchez, E., Colmenarejo, M. F., Vicente, J., Rubio, A., \& Borja, R., (2007). Use of the water quality index and dissolved oxygen deficit as simple indicators of basins pollution. Ecol. Indic. 7, $315-328$.

Santoso, S. (2014). Statistik Parametrik. Jakarta : Elex Media Komputindo.
Șener, S., Sener, E., \& Davraz, A. (2017). Evaluation of water quality using water quality index (WQI) method and GIS in Aksu River (SW-Turkey). Science of the Total Environment, 584, 131-144.

Simoes, F. D. S., Moreira, A. B., Bisinoti, M. C., Gimenez, S. M. N., \& Yabe, M. J. S. (2008). Water quality index as a simple indicator of aquaculture effects on aquatic bodies. Ecological Indicators, 8, 476-484.

Sulaiman, W., (2004). Analisis-Analisis Regresi Menggunakan SPSS. Yogyakarta. Andi.

Supranto J. (2010). Statistik Teori dan Aplikasi. Jakarta: UI Press.

Suriawiria U. (2005). Mikrobiologi Dasar. Jakarta: Papas Sinar Sinanti.

Suryana, R. (2013). Analisis Kualitas Air Sumur Dangkal di Kecamatan Biringkanayya Kota Makassar. Skripsi. Makassar: Jurusan Sipil Fakultas Teknik Universitas Hasanuddin.

Syamsir, Birawida, A. B., \& Faisal, A. (2019). Development of Water Quality Index of Island Wells in Makassar City. IOP Conf. Series: Journal of Physics: Conf. Series 1155 (2019) 012106 IOPPublishing.

Tsegaye, T., Sheppard, D., \& Islam, K. R. (2006). Development of Chemical Index as a Measure of In-Stream Water Quality in Response to LandUse and Land Cover Changes. Water Air Soil Pollut 174, 161-179.

Wardhana, W. (2004). Dampak Pencemaran Lingkungan. Yogyakarta: ANDI.

Widaningrum, Miskiyah \& Suismono (2007), Bahaya Kontaminasi Logam Berat Sayuran dan Alternatif Pencegahan Pencemarannya. Buletin Teknologi Pasca Pertanian, 3, 1-8.

Wuana, R. A., \& Okieimen, F. E. (2011). Heavy metals in contaminated soils: a review of sources, chemistry, risks and best available strategies for remediation. International Scholarly Research Notices, 2011.

Yidana, S. M., \& Yidana, A. (2010). Assessing water quality using water quality index and multivariate analysis. Environmental Earth Sciences, 59(7), 1461-1473.

Yuliani, N., \& Lestari, N. A. (2017). Kualitas Air Sumur Bor di Perumahan Bekas Persawahan Gunung Putri Jawa Barat. Research Report, 116122. 